\title{
同一性と親密性の危機の解決における性差
}

一一自我同一性地位の Rasmussen の EIS による併存的妥当性の検討一

$$
\text { 高 橋 裕 行* }
$$

\section{SEX DIFFERENCES IN THE RESOLUTION OF IDENTITY AND INTIMACY CRISIS}

-An Examination of the Concurrent Validity on Ego Identity Status by Rasmussen's EIS

\author{
Hiroyuki TAKAHASHI
}

The first purpose of this study was to examine the concurrent validity of Ego Identity Status by using self-reported measure of Rasmussen's EIS. Its second purpose was to investigate sex differences in the resolution of identity and intimacy crises. Method: An EIS was first administered to 68 male and 66 female university students. Subjects were categorised as high and low in ego identity on the basis of EIS scores as follows : high if their EIS score was greater than third quartile, and low if their EIS score was less than first quartile. A semi-structured interview of ego identity and intimacy was then done to 15 male and 15 female students who were categorized as high, and 15 male and 15 female students considered as low. Results : In both sexes, more subjects classfied as high than subjects classified as low were in the higher identity statuses. In all areas except sex role, male and female demonstrated similar patterns of identity crisis resolutions. More females than males were in the higher intimacy statuses. More male than female were associated between identity and intimacy crisis resolution.

Key words : Identity status, intimacy status, concurrent validity, sex differences.

自我同一性対同一性拡散，親密性対孤立は，Erikson （1956）が青年後期から成人初期にかけて優位となる心理 社会的な危機解決の両極的な所産について論考したもの である。Erikson は, 人生周期における自我同一性対同一 性拡散の段階を, 職業的, イデオロギー的傾倒 (commitment）を促進する時期，親密性対孤立の段階を，自分が 有意な犠牲や妥協 (1963, p263) を必要としても自己を他 者との提携 (affiliation) や協力関係への傾倒を促進する時 期と考えている。

自我同一性に関する研究は，ここ20年, Marcia (1966) の半構造的な面接 (同一性地位面接)を通した同一性地位 のアプローチによる検討が優位となってきている。同一 性地位のアプローチは，同一性危機の解決のプロセスに 伴なう危機 (crisis) と傾倒の心理社会的な 2 つの基準の 組合わせにより，各人を質的に異なる 4 つの同一性地位 のいずれかに位置づけるものである。このアプローチは， 旧来の質問紙法の $Q$ 分類などに示される同一性次元のア プローチが同一性に込めた人生の危機への対処様式を考

* 福井大学. (Fukui University)
察した Erikson (1956) の含蓄を十分に反映させていな いとの批判から考案されたものである。同一性次元のア プローチとは同一性達成と同一性搪散とを両極とする一 次元的連続体を想定して, 各人が持つ同一性危機の解決 に伴なら諸特徵の程度によりこの連続体に位置づける ものである。

Marcia の危機と傾倒の考案は, 同一性形成過程の力 動的な側面を積極的にアプローチする方法として多数の 研究を誘発してきている。多くの研究は, 同一性地位面 接の内容的妥当性や, 同一性地位の構成概念的妥当性, 信頼性などを検討しており, 近年, これらの研究を展望 した論文が公刊されているが (Bourne, 1978 ; Waterman, 1982 ; 高橋, 1984), 共通に, 同一性地位の併存的妥当性 を検討した研究が著しく少ないと指摘している。僅かに， Adams et al (1979) は同一性地位のアプローチの枠組み の中で, 質問紙 (Objective Measure of Ego Identity Scale) を作成している。彼らは 4 つの同一性地位それぞれを表 わす 6 項目, 計 24 項目からなる尺度を作成し，再検查法 による信頼性や同一性地位面接による併存的妥当性, 予 測的妥当性を検討している。地位面接と彼らの尺度とに 
よる同一性地位の比較は，類似しているが同一ではなく， この尺度が面接での評定によるモラトリアムと同一性拡 散とを十分に識別しないことを示している。彼らの検討 方法は，同一性地位の評定基準が用いられた標本により 変動することや，定義された評定基準によるモラトリア 厶の者の大量出現, 論理に疑問を抱かせる安易な移行地 位の設定などの問題が 残る。加藤 (1986) は，同一性地 位面接の併存的妥当性の検討の重要性を指摘し, 同一性 確立あるいは同一性混乱の特徵が記述された同一性次元 の質問紙を作成し，これと自ら作成した同一性地位のア プローチの枠組みの中の質問紙 (1983) との併存的妥当性 を検誩している。しかし，両尺度はともに質問紙であり， 検討課題の要諦となる同一性地位面接による同一性地位 の評定が行われていなく，一種のトートロジーを形成し ている。そこで，本研究の第1の目的は，同一の対象に 同一性地位面接と同一性次元の質問紙を実施し，同一性 地位アプローチの併存的妥当性を検砷することである。

本研究の第 2 の目的は，同一性と親密性の危機解決に 関する性差の検討である。Erikson (1968) は親密性発達 に抢汸る同一性の役割を強調し「真の他者との提携は， 堅固な自己画定の結果であり，検証でもある」と述べて いる。親密性は, Orlofsky et al (1973) が Erikson の 理論から抽出した 3 つの基準により，構成概念の操作的 定義空試みている。第 1 の基隻は，同性，異性との親密 な関係の有無であり，第 2 は，継続する傾倒した性愛的 な関倸の有無であり, 第 3 は, 仲間関係の深浅である。 彼ら泣, 半構造的な「親密性地位面接」 (intimacy status interview）を行うことにより，これらの基準の組合わせ から, 親密性 (intimate), 前親密性 (preintimate), ステ レオタイプ (stereotyped), 偽親密性 (pseudintimate), 孤 立 (isolate) の 5 つの「親密性地位 (intimacy status)」を 導き出している。親密性地位の慨略は，以下の通りであ る。親密性の者は，同性や異性の友達と深い，開かれた 関係を形成し，異性との継続する傾倒した愛情関係に関 与している。前親密性の者は，傾倒する異性との愛情関 係にアンビバレントであることを除き，親密性の者の友 人関係と似ている。ステレオタイプの者は, 継続した複 数の同性や異性との友達関係を持つが，これらの関係は 個人的なコミュニケーションが少なく，表面的である。 偽親密性の者は, 継続した異性関係を持つが, 深い感情 の共有や自己解放というより，慣習的な役割に規定され， 同性との関係はステレオタイプと同じである。孤立の者 は，偶発的に出会う知已を除き，仲間との個人的な関係 を欠いている。親密性地位の構成概念的妥当性は, 親密 性や前親密性の男子が偽親密性やステレオタイプの者よ
り対人関倸の認知 (Orlofsky, 1976) や，情感の認知 (Orlofsky \& Ginsburg, 1981) などの測度で高得点することで 検証されている。

Marcia と Orlofsky et al とが，それぞれ，同一性地 位と親密性地位とのアプローチを提唱して以来, 多くの 研究は, 主に男女大学生を対象に, 同一性や親密性の危 機解決を検討している。これらの研究の実証的知見の中 で明らかにされてきている重要な問題の一部として，い くつかの性差に関する問題が挙げられる。第 1 は, 男女 間で同一性地位の相対的な適応性の位置づけが異なる可 能性である。第 2 は, 男女間で Erikson の人間発達漸 成図式に打汀る同一性伦機と親密性危機との発達的経路 が異なる可能性である。第 3 は，男女間で重要とされる 領域が異なり，親密性地位を予測する領域が異なる可能 性である。

第 1 の問題恃，男性では，同一性達成とモラトリアム とが相互に類似して一群を，早期完了と同一性拡散とが 一群を構成し，両群問に多くの従属尺度で差異が見出さ れている。しかし，女性を対象とした研究のいくっか流 同調性や場の依存性，制御の所在性 (locus of control), 専攻の難易性，不安，自尊感情などの従属変数を検討し， 男性と異なる結果を示している。これらの研究は, 女性 のみを対象として, 早期完了は適応的であり, モラトリ アムは適応的でないと結論している。最近の研究は, Orlofsky (1978) の批判を受けて，男女の標本を，同時 に，同一の母集団から抽出する手続により，そラトリア 么の女性が同一性達成の女性と比肩する高いパフォーマ ンスの結果を得ている。Orlofsky は，男女大学生を対 象に，達成動機を従属変数として同一性地位の性差を検 討し，達成動機注男女とも，同一性達成やモラトリアム の者が早期完了や同一性拡散の者より高い結果を得てい る。Ginsburg \& Orlofsky (1981) は, パーソナリティ の媣い層を測定する Loevinger の自我発達測度を用い て，モラトリアムの女性は早期完了の女性より自我発達 の高い段階である「良心的段階」の者が多いことを見出 している。Read et al (1984) は, 複雑な状況での他者 への影響行動様式を検討し，同一性達成とモラトリアム の女性は，多大な情報処理能力が高く，影響行動も置か れた状況の葚案を指摘し，精力的に言語的に訴えるが， 早期完了の女性山多㥞な認知の分析・統合の能力が最も 低く, 影響行動も権威的，操作的（報酬の分与）であるこ とを明らかにしている。

第 2 の問題は，男女間での同一性や親密性の危機の発 達的経路が異なる可能性である。Erikson (1968) は, 男 性が同一性危機の解決後に親密性危機に向からが，女性 
は同一性危機と親密性危機との解決が並行すると仮説し ている。Josselson (1973) は, 事例の検討により女性の 同一性形成が親密性形成の過程と並行しているという印 象を受けると述べ, 女性は同一性の強化と親密性の深化 とに相互性があるとしている。Schiedel \& Marcia(1985) は, 男性では同一性地位と親密性地位との間に有意な連 関があるが，女性では有意な連関が認められないことを 示している。高橋・関口（1986）は，女子大学生を対象 に全体的な同一性地位が高くとも, 親密性地位が高いと は限らないといら結果を得ている。しかし, 芳川・園田 (1985) は女子大学生を対象に自我同一性の高い群が親密 性地位も高いことを見出している。

最後の問題は, 前提として, 領域間の同一性地位の謂 定が全体的同一性地位の評定に収斂されるのでなく, 保 たれるということである。同一性地位面接を用いた研究 の多くは，3 領域の同一性地位を総合して 1 つの全体的 な同一性を決定してきている。Erikson (1956) は, 自我 同一性の発生論の中で，同一性を成人以前の全ての同一 視の止揚的性質を荷った分割を許さないゲシュタルトと して考えている。Matteson (1977) は, 領城間の同一性 地位を総合的に評定した全体的同一性地位が何を意味し ているのか不明であると指摘し，同一性を各領域の同一 性地位プロフィールとして検討することが研究に生産的 であると考えている（全体的同一性地位と領域間の同一性地 位との関連については, 考察において論考する)。領域別に同 一性地位を検討した研究は, 必ずしも多数行われていな いが，性差を中心に問題点を整理すると, 以下の 2 つの 問題に下位分類される。(1)男女間で重視される領域が異 なる可能性，(2)男女間で重視される領域での同一性の確 立が親密性達成を最も予测する可能性, などである。領 域の性差の検討に伴なう2つの問題は, 最初に同一性地 位を検封した Marcia \& Friedman (1970) のストラテジ 一の中に, 既にその萌芽が認められる。彼らは, Erikson の呾える, 女性は自らの同一性を男性との関与を通じて 現わすという考えに基ゔいて，旧来の同一性地位面接の 領域に婚前交涉を加え，女性は婚前交渉の領域での同一 性危機解決が重要と考えている。1つ目の問題に関して, Schenkel \& Marcia (1972) は, 女性のみを対象に, 領 域別の同一性地位を検討している。彼らは, 婚前交涉の 領域での同一性地位が他の領域での同一性地位より従属 変数の分散を最も予測し，ついで宗教の領域での同一性 地位が予測するが，職業や政治の領域での同一性地位は 予測性が低いことを見出している。Waterman \& Nevid （1977）は, 男女大学生を対象に, 女性が男性より婚前交 渉の領域で, 男性が女性より職業の領域で, それぞれの
同一性危機を体験していると仮説して検討を行い，前者 の仮説が支持され，後者は支持されなかった。女性は， 婚前交涉の領域で危機を体験している者が多く，同一性 達成と早期完了との 2 峰分布を示すが，男性は危機を体 験している者が著しく少なく早期完了が多いことが見出 された。Matteson 注, Macia \& Friedman(1970) の婚 前交涉の考えでは著しく限定されてしまうことを批判し， 関連する幅広い性役割への考え方に代えている。技は, さらに宗教を価值観に代え，デンマークの男女高校生に 面接を行っている。結果は，男女とも，性役割と価徝観 の領域で高い探索と傾倒が認められ，この 2 領域での探 索と傾倒がパーソナリティ諸変数の分散を予測している。 Hodgson \& Fischer (1979) は, 旧来の 3 領域に, 婚前 交涉と性役割の領域を加えて領域別の同一性達成度の性 美を検討している。結果の処理に際して, 旧来の 3 領域 で高い同一性地位にある者を「男性型経路」, 婚前交涉 と性役割の領域で高い同一性地位にある者を「女性型経 路」，5領域でいずれも高い同一性地位にある者を「アン ドロジニィ型経路」と分類している。結果は職業や政治, 宗教において男性が女性より，婚前交涉や性役割におい て女性が男性より高い同一性地位の者が多い。Waterman (1982) は，婚前交涉や性役割の領域を含む研究を 通覧し, 研究の数が少ないため結論を保留しながら, 性 的行動・態度の領域において男女間に同一性危機の解決 パターンが異なる可能性を示唆し，これを除く他の領域 においては, 男女が同様の同一性危機の解決パターンを 経過すると述べている。

下位分類による 2 目の問題は, 領域別の同一性地位 と親密性地位との関係性についてである。この関係性を 最初に実証的に検討したのは, Hodgson \& Fischer (1979) である。彼らは, 同一性地位面接と親密性地位面 接を行い, 同一性と親密性の性差を検討している。男性 型や女性型，アンドロジニィ型などの経路に加えて，い ずれの領域でも低い同一性地位にある未分化型の 4 群に 分け，親密性地位との関係を検討したところ，男性では アンドロジニィ型の者が他の経路の者より高い親密性地 位 (親密性と前親密性) にあるが，女性では未分化型を除 く経路間で高い親密性地位の者の分布に有意な营異が見 出されていない。また, 女性は男性より高い親密性地位 にある者が多い。これらの結果は, 男性では全ての領域 での同一性危機の解決が親密性獲得の前提になるが，女 性では親密性危機の解決が同一性危機の解決と並行方る 可能性を示唆したものである。Kacerguis \& Adams (1980) は, Schenkel \& Marcia (1970) に従い, 女性の 同一性危機解決が男性と比較して職業や政治より刘人関 
係の確立や維持と関連する提携（affiliation）に依拠して いるため, 宗教の領域での同一性地位が親密性地位を予 測すると仮説しているが，結果は仮説が支持されず，男 女とも職業の領域での同一性地位が親密性地位を予測し ている。これに対して, Fitch \& Adams (1983) は同一 の仮説を用いて，仮説通りの結果を得ている。しかし， 両研究とも, 親密性の展開と関係して重視されてきてい る性役割の領域を含めて検討していない。Tesch \& Whitbourne (1982) は, 親密性の仜機に直面していると 考えられる, 平均年齡25荗の大学卒業生を対象に, 領域 別の同一性地位と親密性地位との連関を検討しているが, 男交込みにして結果を報告しているため性差が明らかで ない。このように, 性差を中心に領域別の同一性地位と 親密性地位との関係を検討した研究は, 各領域の同一性 地位を経路に統合している，性役割の領域を含んでいな い, 性差の検討を行っていない，などの問題があるため， 未だ決定的な結果は見出されていない。

本研究では, 同一性地位面接と自我同一性の質問紙を 同一の対象に実施し，同一性地位概念の併存的妥当性を 検討することを第 1 の目的とする。その際, 妥当性の問 題を明䀢にするため, 自我同一性の質問紙の得点の中位 の者は除外した。あわせて，性差について包括的に検討 するため, 各領域の同一性地位と親密性地位の特徽, 各 領域の同一性地位と親密性地位との関連をあきらかにす ることを第 2 の目的とする。

\section{方法}

\section{1. 被面接者}

被面接者は，同一性の危機のみならず，親密性の危機 にも直面している可能性が高いと考えられる， $3 ・ 4$ 年 生の男女それぞれ30名, 計60名である。男女各30名は, 男女それぞれ，70名弱の集団のなかから，後述するRasmussen (1964) の質問紙 (Ego Identity Scale : EIS) の総 得点により低群 (第一四分位数以下の者) 15名と, 高群（第 三四分位数以上の者) 15名の者が選ばれている。

\section{2. 测度}

同一性地位面接 地位面接では, 領域の選定にあたり， Matteson (1977), Waterman \& Nevid (1977), 無藤 （1979）を参考に, 宗教を価值観に代え, 性差の検討のた めに性役割を加え, 職業, 価值観, 性役割の 3 領域とした。 同一性地位の評定は，Matteson の「探索と傾倒におけ る 4 段階評定」に準拠し, 領域別の地位判定後, 全体的 同一性地位を決定した。全体的同一性地位の評定を客観 的に行うため, 無藤に做い, 微妙なニニアンス（地位の 移行過程にあるとみなしうる場合）を評定に反映させる必要
がある場合, 副評定を添えた。全体的同一性地位評定は, 「危機と傾倒」と「主評定と副評定」に基づく 3 領域の 単純合計としてある程度自動的に決定された。

評定の信頼性は，2名の独立した評定者間の一致度に よって検討した。評定者の 1 名は筆者であり，他の評定 者は筆者が 2 年間同一性地位や親密性の構成概念を指導 してきた学部生である。評定の一致した割合は， $82.8 \%$ であった。先行研究と比較して, 比較的高い一致率とい える。評定が不一致の場合, 評定者閒で一致が得られる よう合議し, 最終的には主評定者 (筆者)の評定に拠っ て分析を行った。

自我同一性の質問紙 Rasmussen (1964) は最も使用頻 度が高く信頼性が高い (Waterman, 1982) とされている EIS を考案している。EIS は, Erikson の発達漸成図 式の I 段階からVI段階までの意味内容に基ついて質問文 が構成された, 各段階12項目の計72項目からなる質問紙 である。平野・宮下 (1981) は EIS の邦訳を試み, 折半 法による信頼性の検討を行い, 高い相関倸数を報告して いる。本研究では, 平野・宮下が邦訳した尺度を用いた が, 訳が硬く意味が通りにくい質問文は適宜修正を行っ た。解答法は，本来 2 件法であるが，質問文が微妙であ ることを考慮して 4 件法とし, 安易な解答態度を防止す るため,「どちらでもない」とする中点を意図的に除外 した。同一性を方向つける肯定的な反応に 4 点, 否定的 な反応に 1 点として得点化を行った。EIS は, 男子68名, 女子66名に個別で行われた。得られた得点分布は, 男子 が146点から255点まで（平均值は206.29, 標準偏差は20.00), 女子が 158 点から 255 点まで（平均㑷は203.14, 標準偏差は 16.80)であり，正規性の検定は試みていないが，ほぼ正 規分布と見なせるものであった。男女閒に有意な得点差 は認められない。これらの分布に基づいて，男女別々に， 第一四分位数と第三四分位数が求められた。第一四分位 数は，男女それぞれ, 191, 192であり，第三四分位数は， 221,216であり，比較的近似した值といえる。

親密性地位面接 Schiedel \& Marcia (1985) やTesch \& Whitbourne (1982) の親密性地位面接の項目を参考 にして,「友情」と「交際」の 2 領域からなる面接項目 が作成された。前者は「最も親しい同性の友人（例えば 親友）との関係」に関連する面接項目，後者は「おつき あいする異性との関係」に関連する面接項目である*。

親密性地位の評定は, Orlofsky et al (1973) の提唱し た 3 つの基準に準拠して行わ扎た。時間的継続性と質問 項目の「影響内容」や「相手との関係に対する認識」,

これらの面接項目の詳細については, 筆者に問い合わせら れたい。 
「自己にとっての相手の存在の意味」などを基に，自 己の気持の解放性, 関係への自我関与度などの質的 次元を通して, 相手への傾倒が評定されることによ り, 親密性地位が決定された。親密性の全体的評定に おいて，性的関係が非性的関係より重みゔけられた。

評定の信頼性は，2名の独立した評定者間の一致 度によって検討した。評定の一致した割合は, $88.3 \%$ であった。評定者は, 同一性地位の評定者と同一であ る。先行研究は $75 \%$ ～95\%の一致を報告しているの で, 本研究の信頼性は, 比較的高い一致率といえる。 評定が不一致の扱いは，同一性地位の評定と同一で ある。

\section{3. 手続}

個別に EIS を配布して記入を 依頼し，3，4 日 後, 回収して採点し, 前述の第一四分位数以下と第 三四分位数以上の得点の者に被面接者の依頼を行っ た（興味深いことに，低得点者のなかにのみ，面接の依頼 に対する拒否が若干認められ心)。面接の依頼の 1 週間 前後に，被面接者の調整のつく日に面接日を設定し， 同一性地位面接と親密性地位面接が，この順で行わ れた。両面接に要する時間は，45７0分ほどである。 面接の内容は, テープレコーダーに録音され, 後に 評定に用いられた。

4. 実施時期 1985年 9 月から12月までである。

\section{結果}

\section{1. 併存的妥当性の検討}

EIS 得点の高・低群間における各領域及び全体の同一 性地位を，男女別に，整理したのが TABLE1である。 高・低群間の各領域及び全体の地位比較のため, 男子で は 4 (同一性地位) $\times 2$ (高・低群)，女子では 3 (同一性地位) $\times 2$ (高・低群) 分子による直接確率法の統計的検定を 行った。男子では, 職業 $\left(\mathrm{P}=1.0559 \times 10^{-3}\right)$, 価值観 (P $\left.=1.6754 \times 10^{-3}\right)$, 性役割 $\left(\mathrm{P}=4.8724 \times 10^{-3}\right)$ のいずれの領 域でも, 高・低群閒の地位分布に有意な差異が認められ， 全体的地位においても有意な差異 $\left(\mathrm{P}=1.4079 \times 10^{-4}\right)$ が認 められた。女子では男子と同様に, 職業 $\left(\mathrm{P}=9.5308 \times 10^{-3}\right)$, 価值観 $\left(\mathrm{P}=1.9359 \times 10^{-4}\right)$, 性役割 $\left(\mathrm{P}=6.3886 \times 10^{-3}\right)$ のい ずれの領域でも，高・低群間の地位分布に有意な差異が 認められ，全体的地位に执いても有意な差異 $(\mathrm{P}=4.0562$ $\left.\times 10^{-3}\right)$ が認められた。性役割の領域を除き職業と価值 観の領域及び全体の地位において，男女共通に，高群は 同一性達成の者が最も多く，低群では早期完了の者が最 も多い。また，同一性拡散の者は，男子の高群に皆無で あるが，男子の低群にはいずれの領域及び全体的地位に
TABLE 1 Proportions and Frequencies of Males and Females in Identity Status for High and Low Groups in EIS Scores

\begin{tabular}{|c|c|c|c|c|}
\hline \multirow[b]{2}{*}{ Category } & \multicolumn{3}{|c|}{ Identity Status } & \multirow{2}{*}{ Diffusion } \\
\hline & Achievement & Moratorium & Foreclosure & \\
\hline & \multicolumn{4}{|c|}{ Male } \\
\hline \multicolumn{5}{|l|}{ Occupation } \\
\hline High & $.73(11)$ & $.20(3)$ & $.07(1)$ & \\
\hline Low & $.27(4)$ & $.20(3)$ & $.33(5)$ & $.20(3)$ \\
\hline \multicolumn{5}{|l|}{ Value } \\
\hline High & $.80(12)$ & & $.20(3)$ & \\
\hline Low & $.33(5)$ & $.07(1)$ & $.33(5)$ & $.27(4)$ \\
\hline \multicolumn{5}{|l|}{ Sex Role } \\
\hline High & $.13(2)$ & $.13(2)$ & $.73(11)$ & \\
\hline Low & & $.20(3)$ & $.53(8)$ & $.27(4)$ \\
\hline \multicolumn{5}{|l|}{ Overall } \\
\hline High & $.73(11)$ & $.13(2)$ & $.13(2)$ & \\
\hline Low & $.13(2)$ & $.33(3)$ & $.47(6)$ & $.07(4)$ \\
\hline \multicolumn{5}{|c|}{ Female } \\
\hline \multicolumn{5}{|l|}{ Occupation } \\
\hline High & $.60(9)$ & $.20(3)$ & $.20(3)$ & \\
\hline Low & $.20(3)$ & $.33(5)$ & $.47(7)$ & \\
\hline \multicolumn{5}{|l|}{ Value } \\
\hline High & $.80(12)$ & $.13(2)$ & $.07(1)$ & \\
\hline Low & $.20(3)$ & $.13(2)$ & $.67(10)$ & \\
\hline \multicolumn{5}{|l|}{ Sex Role } \\
\hline High & $.47(7)$ & & $.53(8)$ & \\
\hline Low & $.27(4)$ & $.33(5)$ & $.40(6)$ & \\
\hline \multicolumn{5}{|l|}{ Overall } \\
\hline High & $.67(10)$ & $.13(2)$ & $.20(3)$ & \\
\hline Low & $.20(3)$ & $.20(3)$ & $.60(9)$ & \\
\hline
\end{tabular}

Note. Number in decimal form indicate proportions, whereas those in parentheses indicate frequencies.

おいても散見されている。

\section{2. 同一性地位の性差}

男・女間の同一性地位の比較のため, 高群では 3 （同 一性地位) $\times 2$ (男・女), 低群では 4 (同一性地位) $\times 2$ (男・ 女）分子による直接確率法の統計的検定を行った。高群 では, 職業 $(\mathrm{P}=.0866)$ と価值観 $(\mathrm{P}=.0690)$ の領域で男・ 女間の地位分布に有意な差異が認められないが，性役割 $(\mathrm{P}=.0175)$ の領域においてのみ, 有意な差異が認められ た。全体的地位においては，有意な差異 $(\mathrm{P}==.1364)$ が認 められなかった。高群では, 性役割の領域を除く領域及 び全体的な地位において，男女とも同一性達成の者が多 い。性役割の領域において, 男子は早期完了の者が著し く多いが, 女子は同一性達成か早期完了かの双峰分布を 示している。低群では, 職業 $(\mathrm{P}=.0100)$, 価值観 $(\mathrm{P}=$ .0032), 性役割 $\left(P=1.0841 \times 10^{-3}\right)$ のいずれの領域でも 男・女間の地位分布に有意な差異が認められ，全体的地 位においても，有意な差異 $\left(P=6.4531 \times 10^{-3}\right)$ が認められ た。低群では，いずれの領域でも全体的な地位において も，男女共通に早期完了の者が最も多いが，男子におい てのみ, 同一性拡散の者が認められた。 


\section{3. 各領域の同一性地位と全体的同一性地位との連関}

EIS 得点の高群・低群間で, 男女それぞれ，各領域及 び全体的な同一性地位分布に有意な差異が認められてい るが，各領域の地位と全体的地位との連関の性差を検討 するために，高・低群を無視して男女別に集計が行われ た。引き続いて, 統計的検定の要請のため, 各同一性地 位は高い地位 (同一性達成とモラトリアム) と低い地位 (早 期完了と同一性払散) の 2 群に圧縮 された。各領域の地位 と全体的地位との関連は, $2 \times 2$ 分子の直接確率法によ って検討が行われた。男子では, 価值観 $(\mathrm{P}=1.1674 \times$ $\left.10^{-4}\right)$, 性役割 $(\mathrm{P}=.0156)$ の領域において有意な連関が

TABLE 2 Frequencies of Males and Females for High and Low Groups in EIS Scores by Principled Values

\begin{tabular}{l|cc|cc}
\hline & \multicolumn{2}{|c|}{ Male } & \multicolumn{2}{c}{ Female } \\
Principled Value & High & Low & High & Low \\
\hline Self-actualization & 7 & 2 & 9 & 2 \\
Exploration of values & 4 & 4 & 4 & 4 \\
Interpersonal relationship & 3 & 2 & 1 & 5 \\
Others & 1 & 3 & 1 & 4
\end{tabular}

認められたが，職業においては認められなかった。有意 な連関が認められた領域について連関係数を求めたとこ 万，価值観では .7222, 性役割では .4504の值が得られ た。女子では, 職業 $\left(\mathrm{P}=2.5207 \times 10^{-3}\right)$, 価値観 $(\mathrm{P}=2.1747$ $\left.\times 10^{-5}\right)$ の領域でも有意な連関が認められたが，性役割 においては認められなかった。有意な連関が認められた 領域について連関係数を求めたところ, 職業では . 5774 , 価值観では .7907の值が得られた。男女とも，価值観の 領域での連関係数が最も高く, 価値観の領域での地位が 全体的地位と最も高く連関している。

\section{4. 価值観の内容}

価值観の領域での地位と全体的地位との連関係数が最 も高いため, 価值観の内容を, 無藤（1979）を参考にし て, 自己実現, 価值観の追求, 対人関係, その他の $4 つ$ に分汁，男女別，EIS 得点の高・低群別に整理し たのが TABLE 2 である。男女別に高・低群間の 価做観の内容比較のため, 対人関係・その他を 1 つの群に圧縮し， 3 (侕值観の内容) $\times 2$ (高・低群) 分子による值接確率法の統計的検定を行った。男 女とも，それぞれ高・低群間に, $\mathrm{P}=.0116, \mathrm{P}$ $=1.3650 \times 10^{-3}$, の危険率で有意な差異が認めら れた。高群は自己実現が多く, 低群は対人関係と その他が多い。さらに, 価值観の内容の性差比較 のため, 高・低群別に， $3 \times 2$ (男・女) 分子によ る直接確率法の統計的検定を行った。高・低群共
通に，男女間で有意な差異は認められなかった。佂値観 の内容は, 被面接者の性に関係がなく, EIS の得点の高 低に関係しており, 高群は自己実現が多く, 低群は対人 関係・その他が多い。

\section{5. 高・低群の親密性地位とその性差}

EIS 得点の高群・低群間における親密性地位を, 男女 別に, 整理したのがTABLE 3 である。高・低群別, 男女 別のいずれの群にも, 孤立の地位の者は認められなかっ た。高・低群間の親密性地位の比較のため, 男女別に, 4 (親密性地位) $\times 2$ (高・低群) 分子による 直接確率法の 統計的検定を行った。男女とも，それぞれ， $\mathrm{P}=6.4531$ $\times 10^{-5}, \quad \mathrm{P}=7.9097 \times 10^{-3}$, の危険率で高・低群閒に有 意な差異が認められた。男子は, 高群に親密性や前親密 性の地位の者が多いが，低群に偽親密性やステレオタイ プの地位の者が多い。女子は, 高群に親密性の地位の者 が多いが, 低群に前親密性の地位の者が多い。

高・低群間で, 男女それぞれ, 親密性地位分布に有意 な差異が認められたが, 親密性地位分布の性差を検討す るため, 男女別に, 高・低群が 1 群にまとめられて集計 された。4 (親密性地位) $\times 2$ (男・女) 分子による直接確 率法の統計的検定を行ったところ, $\mathrm{P}=3.3756 \times 10^{-4}$ の 危険率で有意な差異が認められた。男子は, 前親密性の 者が最も多く，ついでステレオタイプの者が続くが，女 子は親密性と前親密性の者とで折半されている。

\section{6. 各領域及び全体の同一性地位と親密性地位との連関}

高・低群閒で, 男女それぞれ, 親密性地位分布に有意 な差異が認められたが, 各領域の同一性地位と親密性地 位との連関の性差検討のため, 高・低群を無視して男女 別に集計が行われた。各領域の同一性地位及び全体的同 一性地位と親密性地位との関連を, 男女別に, 整理した のが TABLE 4 である。統計的検討の要請のため, 同一 性地位と親密性地位は, それぞれ, 高い同一性地位と低 、同一性地位, 高い親密性地位（親密性之前親密性）と低 い親密性地位 (偽親密性とステレオタイプ)の 2 群に圧 縮

TABLE 3 Proportions and Frequencies of Males and Females in Intimacy Status for High and Low Groups in EIS Scores

\begin{tabular}{|c|c|c|c|c|c|}
\hline \multirow[b]{2}{*}{ Category } & \multirow[b]{2}{*}{ Intimate } & \multicolumn{2}{|c|}{ Intimacy Status } & \multirow[b]{2}{*}{ Stereotyped } & \multirow[b]{2}{*}{ Isolate } \\
\hline & & Preintimate & Pseudintimate & & \\
\hline \multicolumn{6}{|l|}{ Male } \\
\hline High & $.27(4)$ & $.67(10)$ & & $.07(1)$ & \\
\hline Low & $.07(1)$ & $.20(3)$ & $.33(5)$ & $.40(6)$ & \\
\hline \multicolumn{6}{|l|}{ Female } \\
\hline High & $.60(9)$ & $.40(6)$ & & & \\
\hline Low & $.27(4)$ & $.47(7)$ & $.20(3)$ & $.07(1)$ & \\
\hline
\end{tabular}


された。連関の検討は，男女別に， 2 (同一性地位) $\times 2$ (親密性地位) 分子 による直接確率法の統計的検定を行 った。男子では，価值観の領域及び 全体的な同一性地位がそれぞれ， $\mathrm{P}=2.0755 \times 10^{-3}, \mathrm{P}=.0215$ の危険 率で親密性地位と有意な連関が認め られた。有意な連関が認められた領 域について連関係数を求めたところ 価值観では. 5833，全体では.4330の 值が得られた。しかし，女子ではい ずれの領域及び全体の同一性地位も 親密性地位と有意な連関が認められ なかった。

\section{考察}

\section{1. 併存的妥当性の検討}

併存的妥当性の考察に入る前に, 本結果で得られた同一性地位分布を 検討する。本結果で得られた地位分 布が他の研究結果と著しい差異が示 されるならば，併存的妥当性を考察 する以前に，本研究で用いた同一性 地位面接の内容的妥当性の問題が浮 上するからである。 3 領域を総合し た全体的な同一性地位をとりあげる ならば，本邦で同一性地位アプロー チの先鞭をなした無藤（1979）は， 3，4年の男子大学生63名を対象に, 同一性達成が29名，モラトリアムが 4 名, 早期完了が20名, 同一性拡散 が10名の地位分布を見出している。 本結果は，男女をこみにして，同一 性達成が26名，モラトリアムが10名， 早期完了が 20 名，同一性抎散が 4 名であった。本研究の 被面接者の在籍年次は無藤と同一ではあるが，被面接者 が無作為に母集団から選択された者より構成されていな く，しかも男子だけでなく女子をも対象とし，用いられ た面接領域も一部異なるため, 無藤の結果と同一線上で 諭じられないが，モラトリアムと同一性拡散の分布が逆 転していることを除き，比較的近似した結果が得られて おり，高い内容的妥当性が示されたものと考えられる。

本研究では, 併存的妥当性の検討のため, EIS を用い た。男女とも，EIS の高群と低群の間に，差異が見出さ れた。高群は, 男女共通に性役割の領域を除き(闹一性地

Occupation

Moratorium

Diffusion

Value

Achievement

Moratorium

Diffusion

Achievement

Moratorium

Diffusion

Overall

Achievement

Moratorium

Foreclosure

Diffusion
TABLE 4 Frequencies of Males and Females on Intimacy Status by Identity Area

\begin{tabular}{|c|c|c|c|c|c|}
\hline \multicolumn{6}{|c|}{ Intimacy Status } \\
\hline Identity Area & Intimate & Preintimate & Pseudintimate & Stereotyped & Isolate \\
\hline \multicolumn{6}{|c|}{ Male } \\
\hline \multicolumn{6}{|l|}{ Occupation } \\
\hline Achievement & 2 & 10 & 1 & 2 & \\
\hline Moratorium & 1 & 2 & & 3 & \\
\hline Foreclosure & 2 & 1 & 2 & 1 & \\
\hline Diffusion & & & 2 & 1 & \\
\hline \multicolumn{6}{|l|}{ Value } \\
\hline Achievement & 5 & 10 & 1 & 1 & \\
\hline Moratorium & & & & 1 & \\
\hline Foreclosure & & 3 & 1 & 4 & \\
\hline Diffusion & & & 3 & 1 & \\
\hline \multicolumn{6}{|l|}{ Sex role } \\
\hline Achievement & & 2 & & & \\
\hline Moratorium & 1 & 1 & & 3 & \\
\hline Foreclosure & 4 & 9 & 3 & 3 & \\
\hline Diffusion & & 1 & 2 & 1 & \\
\hline \multicolumn{6}{|l|}{ Overall } \\
\hline Achievement & 3 & 9 & & 1 & \\
\hline Moratoriam & 1 & 2 & 2 & 2 & \\
\hline Foreclosure & 1 & 2 & 3 & 3 & \\
\hline Diffusion & & & & 1 & \\
\hline
\end{tabular}

\section{Female}

Achievement 6

位の性差で後述)，同一性達成の者が最も多い。低群は， 同一性達成の者が 3 分の 1 以下であり，早期完了が最も 多い。同一性地位の側から述べるならば，同一性達成， 早期完了と評定される者は，それぞれ EIS で高得点, 低得点であることが多い。この同一性地位と EIS の得 点との関係は，男子のみでなく女子も妥当しており，同 一性地位に対する高い併存的妥当性が得られたものと考 えられる。

しかし，少数ではあるが，高群に早期完了や，低群に 同一性達成が認められている。この理由として, 少なく とも以下の 2 つの問題が考えられる。1つは, EISの得 
点と同一性地位との乘離が認められた被面接者の精査で ある。乘離の多くは，同一性達成が低群代少なからず見 出されたことによる。恶離の理由の一部として，面接の 持つ援助機能に影響を受けたことが考えられる。地位面 接は半構造的に規定されているが，面接者が追求質問 (probe) を工夫することにより，被面接者が自分の世界 を表現し面接者に伝える能力を高めるという援助機能を 内在させている。面接の援助機能が，被面接者の話す能 力を拡大し高い同一性地位の評定を受けたのではないか と考えられる。2 つは，EIS が発達図式の I から V段階 までの内容を尺度化したものであるが，地位面接の領域 との関係が必ずしも明らかでない。さらに本研究の被面 接者は，V段階だけの尺度得点からではなく，I からVI 段階までの尺度の総得点から選ばれている。現状の地位 面接は, Bourne (1978) が指摘する同一性概念の 7 つの 性質を十分反映していず，むしろ青年が現在体験しつつ ある同一性の主観的・意識的な感覚や同一性危機への対 処行動様式を反映させている。この意味で，V段階の尺 度だけで検討する方が一貫した結果を生む可能性を残し ている。

\section{2. 同一性地位の性差}

高群にお污男女間の比較は, 職業や価値観の領域及 び全体での地位に性差は見出されないが，性役割の領域 に扔いてのみ差異が見出されている。女子は, 同一性達 成と早期完了の双峰分布を示すが, 男子は早期完了が著 しく多い。低群の男女閒の比較は，いずれの領域でも全 体でも地位に性差が認められ，女子が男子より高い地位 の者が多い。性役割の領域においては，高・低群問わず， 男女間に性差が認められ，EIS 得点の高低の要因より 生物的な性の所与が大きい。男子注, 性役割の領域に関 する質問の冒頭で, 高・低群問わず，「性役割って何で すか」と問い返すことが多数認められた。他の領域では 面接者の聴き出したいことを一個の質問から連鎖的・自 発的に答元る被面接者も，性役割の領域に限って一個一 個の質問に答えるという形式が少なくない。男子は, 性 役割をあまりに自明すぎて考えたことがないという感想 が多い。他方女子は, 問い返すことは稀有であり, 社会 が求める女性性の役割の受容・反発のいかんを問わず, 絶えず意識されている領域であることが見出された。 Waterman \& Nevid (1977) は, 職業やイデオロギーの 領域で注性差が見出されないが，性役割の領域で性差を 見出している。彼女らは, 男子では危機体験の者は少な く $(27 \%)$, 女子では危機体験の者が多い $(54 \%)$ と述べ ている。本結果は, 性役割の危機を体験している男女が それぞれ $24 \%, 53 \%$ あり，Waterman \& Nevid の值
と酷似している。同一性の形成過程の性差を考えた場合， 女性にとり性役割は葛藤領域であることを示唆している。

男女間で同一性の確立がどの領城で重要であるかを， 各領域の同一性地位と全体的同一性地位との連関により 検討した場合, 価值観の領域での地位が，男女共通に， 全体的地位と最も高い連関を示したが，性役割の同一性 地位は，女子において連関が見出されなかった。男女と も，価值観の領域での同一性確立が最も重要であると考 えられる。Waterman \& Waterman (1971), Waterman et al (1974) らは, 縌断的研究により, 職業の同一性地 位が他の領域の同一性地位を先導することを示している。 Rogow et al (1983) 泣, 各領域の地位と全体的地位との 連関を検討し，最も高いのが宗教であり，最も低いのが 職業であることを見出した。本研究の結果は, 宗教の領 域を含まないため，比較できる研究を持たないが，Rogow et al の宗教を本研究の価值観の領域に読み代える ならば，Rogow et al の結果に部分的支持を与えてい る。佐方・中西(1985) は, 価值観の確立に続いて職業的 同一性が達成されると考えているが，本結果はこれを検 証している。

価値観の領域での地位が全体的地位と最も高く連関し たため, 高低群別, 男女別に, 価值観の内容を検討した ところ，男子，女子それぞれの高・低群開侤差異が見出 されたが，高群，低群それぞれの男・女間に差異は見出 されなかった。男女共通に, 高群は自己実現の内容の者 が多く, 低群は対人関係・その他が多い。男女の同一性 発達の主な問題を検討した先行研究は，男子は同一性の agency（個人内）的側面，女子は同一性の communion (個人間) 的な側面が重要であることを提唱してきている (Josselson, 1977a，1977b)。しかし，本結果は，高群の男 子だけでなく高群の女子も対人関係志向ではなく自己達 成志向を持つ者が多い。また，低群の女子だけでなく低 群の男子も，刘人関係志向が多い。価値観の内容は，旧 来指摘されているような被面接者の生物的な性の所与に 規定されるのではなく，EIS の得点の高低に反映される， 同一性の確立の度合に規定されることを示している。

本結果は, 女子において, 性役割の同一性地位と全体 的同一性地位とに連関が見出されなかった。しかし，女 子は性役割の領域において男子より同一性危機を体験し ている者が多い。これらの結果を葚案すると，女子の同 一性形成に扔いて性役割の領域を看過できないが，Erikson（1968）が提唱するように，性役割が職業や政治， 宗教を陵駕するほど重要な領域でもないように思われる。

本研究では，領域別に同一性地位をとりだし，全体的 な同一性地位との連関を検討したが， 3 領域を総合した 
全体的同一性地位は何を意味しているのであろうか。自 我同一性は, 人格の固有の成長・統合傾向を持つ全体的 な体制である。しかし，同一性の確立の程度を同一性地 位面接でとらえようとする立場は，この「全体」的な体 制をとらえようとする視座と, 背反する部分を内在して いる。同一性地位面接は，そこで措定された特定の次元 に着目し，個人の属性を記述するものである。したがっ て，てこで記述される個人像は，限りなく全体的体制に 近似しているが，本質的に「部分」に着目した構成概念 であり, 全体的同一性地位といえども「部分」的な全体 の構成概念である。しかも，全体的同一性地位は，領域 の同一性地位を構成要素としてではなく，力動的構造の 指標として演繹された構成概念である。同一性地位面接 は，記述上の方法論的制約から部分に着目せざるをえな い。自我同一性の概念は，全体的体制をとらえようとす る, 臨床実践と結びついた自我心理学を背景にしている。 この背反した立場を止揚していくには，全体的同一性地 位が各領域の同一性地位を指標とした「部分」的全体で あり，全体的体制としての自我同一性と賏隔があること の認韵が出発点であろう。

\section{3. 親密性地位の性差}

親密性地位は，男女それぞれ，高・低群間で検討した 場合，高・低群間に差異が見出され，男女とも，高群は 低群より高い地位の者が多い。本結果は，男子だけでな く女子においても，Erikson (1968) の同一性の確立が親 密性の達成の前提となるという一般的な仮説を検証して いる。また, 高・低群を 1 群にまとめた男・女間にも差 異が見出され，女子は男子より高い地位の者が多い。こ の結果は，女子が男子より親密性地位が高いとする Josselson (1973), Hodgson \& Ficher (1979), Schiedel \& Marcia (1985) の結果と一致しており，女性の社会人と しての役割の要請が対人関係の強調であることを反映し ていると考えられる。

\section{4. 同一性地位と親密性地位との連関の性差}

各領域及び全体の同一性地位と親密性地位との連関を 男女別に検討したところ, 男子では価值観の領域と全体 での同一性地位が親密性地位と連関するが，女子ではい ずれの領域及び全体での同一性地位も連関が見出されな かった。先行研究において, 領域別の同一性地位と親密 性地位との連関在検討したものは少なく, 僅かにKacerguis \& Adams (1980) と Fitch \& Adams (1983) の研 究が認められるのみである。多数の先行研究は, 全体的 同一性地位において, 男子では, 同一性を確立することに よって親密性の達成に向け進展しうる結果を示している (Orlofsky et al, 1973 ; Orlofsky, 1976 ; Tesch \& Whitbourne,
1982 ; Schiedel \& Marcia, 1985)。本結果は, 男子の全体 的な同一性地位と親密性地位との連関を示している先行 研究と一致するが，領域別の同一性地位と親密性地位と を関連された研究結果をいずれも支持するものでない。

本結果において，女子では連関が見出されなかった。 同一性地位と親密性地位との連関を検討した先行研究は, Josselson (1973) が事例的な研究を行い, 女性の同一性 形成が親密性形成と並行すると述べ, Schiedel \& Marcia （1985）は同一性地位と親密性地位との連関を見出してい ない。本結果は, これらの先行研究の結果と一致するも のであり, 女子では同一性地位の高低と親密性地位の高 低とが関連なく進展することを示している。さらに女子 は, 男子の同一性形成と親密性形成との直線的な関係と 異なり, 複雑な様相を呈する。女子は同一性地位の高低 が親密性地位の高低と関係なく，しかも女子は男子より 親密性地位が高いことなどから，女子は男子より一般に 親密性の形成が進展しているが，高群が低群より親密性 地位が高いことを考慮すると，女子といえども同一性と 全く無関係に親密性が進展するのではなく, 男子ほど確 固としないにせよ, ある程度の同一性確立の必要性を示 唆するものと考えられる。

今後の課題として，本研究は同一性地位の性差を検討 課題としながら, 同一性地位面接の併存的妥当性の検討 をも意図したため, EIS 得点の中位の者を排除する中で 性差の検討を試みている。本来, 性差の検討が目的なら ば，無作為に抽出された被面接者をもとに分析が行われ るべきである。この意味で, 本結果は最終的なものでは なく, 将来の研究を方向づけ 1 つの試みである。さら に, 本研究の被面接者の標本サイズとその特性を考慮し たとき，本研究で得られた知見を繰りかえすことが必要 と考えられる。また, 親密性地位は, 本来, 男子青年の 対人関係の型の記述を目的に開発されたものであるため, 親密性地位を女性に適応するさいの妥当性への疑問が提 起されてきている。最後に，方法の手続において面接者 が事前に被面接者の EIS 得点を知り得ており, 実験者 の「期待効果」が混入している可能性が考えられる。今 後, これらの問題点を考虑しながら一層の検討が必要で あろう。

\section{引用文献}

Adams, G.R., Shea, J., \& Fitch, S.A. 1979 Toward the development of an Objective Assessment of ego identity status. Journal of Youth and Adolescence, Vol. 8, 223-237.

Bourne, E. 1978 The state of research on ego identity : A review and appraisal. Part 1. Journal of Youth and Adolescence, Vol. 7, 223-251. 
Erikson, E.H. 1956 The problem of ego identity. Journal of American Psychoanalytic association, Vol. 4, 56-121.

Erikson, E.H. 1963 Childhood and Society. (2nd ed.). New York : Norton, 250-284.

Erikson, E.H. 1968 Identity : Youth and crisis. New York : Norton. 9-283.

Fitch, S.A., \& Adams, G.R. 1983 Ego identity and intimacy status : Replication and extention. Developmental Psychology, Vol. 19, 839-845.

Ginsburg, S.D., \& Orlotsky, J.L. 1981 Ego identity, ego development, and locus of control in college women. Journal of Youth and Adolescence, Vol. 10, 297-307.

平野潔・峊下一博 1981 Rasmussen の自我同一性の検 討（I ）（II）中国四国心理学会論文集，14,48-49.

Hodgson, J.W., \& Fischer, J.L. 1979 Sex differences in identity and intimacy development in college youth. Journal of Youth and Adolescence, Vol. $8,37-50$.

Josselson, R.L. 1973 Psychodynamic aspects of identity formation in college women, Journal of Youth and Adolescence, Vol. 2, 3-52.

Josselson, R.L., Greenberger, E., \& McConochi, D. 1977a Phenomenological aspects of psychological maturity in adolescence. Part 1 : Boys. Journal of Youth and Adolescence, Vol. 6, 25-55.

Josselson, R.L., Greenberger, E., \& McConochi, D. 1977b Phenomenological aspects of psychological maturity in adolescence. Part 2 : Girls. Journal of Youth and Adolescence, Vol. 6, 145-167.

Kacerguis, M.A., \& Adams, G.R. 1980 Erikson stage resolution: The relationship between identity and intimacy. Journal of Youth and Adolescence, Vol. 9, 117-126.

加藤厚 1983 大学生における同一性の諸相とその構造 教育心理学研究, Vol. 31, 20-30.

加藤厚 1986 同一性測定における 2 アプローチの比較 検討 心理学研究, Vol. 56, 357-360.

Marcia, J.E. 1966 Development and validation of ego identity status. Journal of Personality and Social Psychology, Vol. 3, 551-558.

Marcia, J.E., \& Friedman, M.L. 1970 Ego identity status in college women. Journal of Personality, Vol. 38, 249-263.

Matteson, D.R. 1977 Exploration and commitment: Sex differences and methodological problems in the use of identity status categories. Journal of Youth and Adolescence, Vol. 6, 353-374.

無藤清子 1979 「自我同一性地位面接」の検討と大学生 の自我同一性 教育心理学研究 Vol. 27, 178-187.

Orlofsky, J.L. 1976 Intimacy status : Relationship to interpersonal perception. Journal of Youth and Adolescence, Vol. 5, 73-88.

Orlofsky, J.L. 1978 Identity formation, achievement, and fear of success in college men and women, Journal of Youth and Adolescence, Vol. 7, $49-62$.
Orlofsky, J.L., \& Ginsburg, S.D. 1981 Intimacy status : Relationship to affect cognition. Adolescence, Vol. 16, 91-100.

Orlofsky, J.L., Marcia, J.E., Lesser, I.M. 1973 Ego identity status and intimacy vs. isolation crisis in young adulthood. Journal of Personality and Social Psychology, Vol. 27, 211-219.

Rasmussen, J.E. 1964 Relationship of ego identity to psychosocial effectiveness. Psychological Reports, Vol. 15, 515-525.

Read, D., Adams, G.R., Dobson, W.R. 1984 Ego identity status, personality, and social influence style. Journal of Personality and Social Psycho$\log y$, Vol. 46, 169-177.

Rogow, A.M., Marcia, J.E. \& Slugoski, B.R. 1983 The relative importance of identity status interview components. Journal of Youih and Adolescence, Vol. 12, 387-400.

佐方哲彦 1985 子ども時代の同一性形成と青年期にお ける同一性地位の発達 中西信男・水野正憲・古市 裕一・佐方哲彦「アイデンティティの心理」有斐閣

Schenkel, S., \& Marcia, J.E. 1972 Attitudes toward premarital intercouse in determining ego identity status in college women. Journal of Personality, Vol. 3, 472-482.

Schiedel, D.G., \& Marcial, J.E. 1985 Ego identity, intimacy, sex role orientation, and gender. Developmental Psychology, Vol. 21, 149-160.

高橋裕行 1984 自我同一性と Marcia の同一性地位面 接: 批評的展望 教育心理学研究 Vol. 32, 320-328.

高橋裕行・関口昇 1986 女子大学生における自我同一 性と親密性の発達的研究 福井大学教育学部紀要 教育科学, Vol. 36, 99-119.

Tesch, S.A., \& Whitbourne, S.K. 1982 Intimacy and identity status in young adults. Journal of Personality and Social Psychology, Vol. 43, 1041 $-1051$.

Waterman, A.S. 1982 Identity development from adolescence to adulthood: An extension of theory and a review of research. Developmental Psychology, Vol. 18, 341-358.

Waterman, A.S., \& Waterman, C.K. 1971 A longitudinal study of changes in ego identity status during freshman year at college. Developmental Psychology, Vol. 5, 167-173.

Waterman, A.S., Geary, P.S., \& Waterman, C.K. 1974 A longitudinal study of changes in ego identity status from freshman to the senior year at college. Developmental Psychology, Vol. 10, $387-392$.

Waterman, C.K., \& Nevid, J.S. 1977 Sex differences in the resolution of identity crisis. Journal of Youth and Adolescence, Vol. 6, 337-342.

芳川玲子・園田雅代 1985 女子大学生の自我同一性・ 親密性 : <II > 親密性地位面接及び追跡調査からみ た自我同一性と親密性との関連 日本教育心理学会 第27回総会発表論文集 58-59.

（1987年 8 月26日受稿） 